\section{An atypical pulmonary presentation of Sjögren's Syndrome}

\author{
Juan M Garcia Puebla*, Arnaldo Nieves Ortiz², Kyomara \\ Hernández Moya ${ }^{2}$, Kimberly C Padilla Rodríguez ${ }^{1}$, Ileana \\ Rivera Burgos ${ }^{2}$, María C Betancourt Quiles ${ }^{1}$ and Ricardo \\ Fernández González ${ }^{1}$
}

${ }^{1}$ Pulmonary Disease and Critical Care Medicine Department, San Juan City Hospital San Juan, PR 00935, Puerto Rico

2Internal Medicine Department, San Juan City Hospital San Juan, PR 00935, Puerto Rico
Received: 28 August, 2020

Accepted: 05 September, 2020

Published: 07 September, 2020

*Corresponding author: Juan M Garcia Puebla, Pulmonary Disease and Critical Care Medicine Department, San Juan City Hospital San Juan, PR 00935, Puerto Rico, Tel: 787-414-2131; E-mail: Juanmipr.7@gmail.com ORCID: https://orcid.org/0000-0001-5820-2965 Keywords: Sjögren's syndrome; Interstitial lung disease; Lip biopsy; Non-sicca

https://www.peertechz.com

\section{Check for updates}

\begin{abstract}
Sjögren's syndrome is an autoimmune disease characterized by exocrine glands lymphocytic infiltration. However, some manifestations can happen outside the secretory glands affecting multiple organs. We report a 63-year-old man without previous history of any rheumatologic disease and negative arthralgias, mucosal or ocular dryness, in which findings of chest CT scan were consistent with interstitial lung disease prompting further diagnostic workup. Given the serological results, Sjögren's syndrome was highly suspicious in our diagnosis for which a lip biopsy was performed revealing the etiology of our patient's interstitial lung changes. To our knowledge, respiratory symptoms are rarely the initial presentation of this disease, heightening a more thorough workup for a patient with interstitial lung disease with an unclear clinical association requiring a biopsy.
\end{abstract}

\section{Background}

Sjögren's syndrome (SS) is an autoimmune disease characterized by exocrine glands lymphocytic infiltration causing typical symptoms of dry eyes and mouth. Some patients may have manifestations outside the secretory glands causing dysfunction of multiple organs, some of which may be the initial presenting symptoms $[1,2]$. It typically presents in women in their fifth or sixth decade, although up to $10 \%$ of cases occur in men and it is also seen in younger people. Interstitial lung disease may be present in up to $20 \%$ of patients with Sjögren's syndrome [3,4]. Subclinical lung disease is even more frequent and often includes evidence of small airways disease and airway inflammation.

\section{Case presentation}

A 63-year-old man with a past medical history of hypertension, coronary artery disease, and heart failure came to the emergency room with worsening dyspnea on exertion and productive cough of several weeks of evolution. The patient affirmed medication and dietary compliance. He denied any history of rheumatologic diseases. Physical exam was remarkable for dry diffuse bilateral crackles, no peripheral edema, absent jugular venous distention, and no hepatojugular reflux. Chest images showed diffuse bilateral pulmonary parenchymal ground glass appearance with lower lobe predominance, thickened septa and pleuroparenchymal fibrotic changes with suspected superimposed infiltrates (Figures 1,2) as well as traction bronchiectasis. Also notable in imaging findings there was an enlarged cardiac silhouette, increased pulmonary vascular markings, and absence of pleural effusions. Arterial blood gases performed at $26 \% \mathrm{FiO} 2$ revealed marked hypoxemia with oxygen saturation at $75 \%$, increased alveolar-arterial $\mathrm{O} 2$ gradient and chronic respiratory alkalosis Figures 3-5.

Laboratory results were significant for elevated sed rate $110 \mathrm{~mm} / \mathrm{hr}$, procalcitonin $0.06 \mathrm{mcg} / \mathrm{L}$, RA Factor of $12.8 \mathrm{IU} /$ 
ml, ANA 1:80 U. Other labs included a non-reactive HIV, and Hepatitis C, CCP IGG $<0.50 \mathrm{u} / \mathrm{ml}$, low complement $\mathrm{C}_{3}$ and C4, Anti SSB 0.70 AI, Anti SSA 5.20 AI, and BNP $730 \mathrm{pg} / \mathrm{ml}$. Echocardiogram showed preserved systolic function, as well as absence of valvulopathies and any wall motion abnormalities.

The patient denied any mucosal dryness, ocular dryness and foreign body sensation, or arthralgias. Despite the optimization of diuretic therapy, the patient remained with hypoxemia and persistence of pulmonary imaging changes for which a diagnostic flexible bronchoscopy was performed. Bronchoalveolar lavage was negative for bacterial growth yet positive for atypical inflammatory epithelial cells. Lung biopsy was negative for fungal or bacterial infection but significant for bronchial tissue reactive cells and acute inflammation. In light of serological results, Sjögren's syndrome was still suspected as a possible culprit of his current interstitial lung disease. Thus, a lip biopsy was done and the histopathological analysis

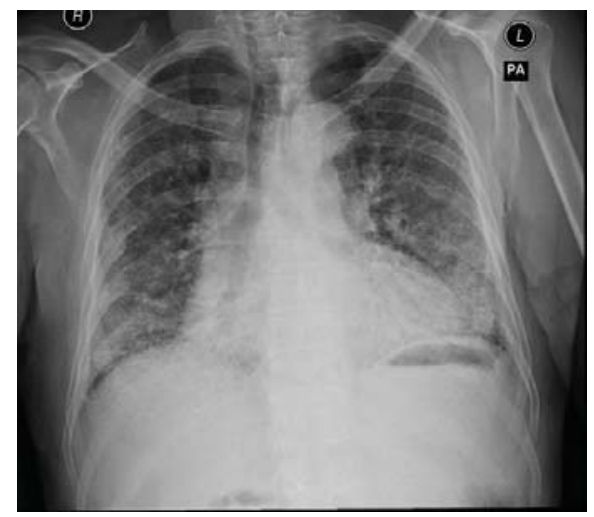

Figure 1: Initial Antero-posterior Chest X-ray.
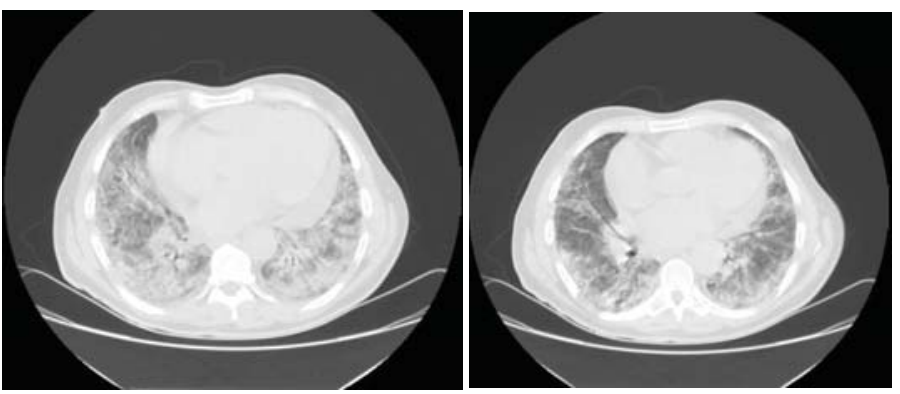

Figure 2: Initial CT scan Axial View.
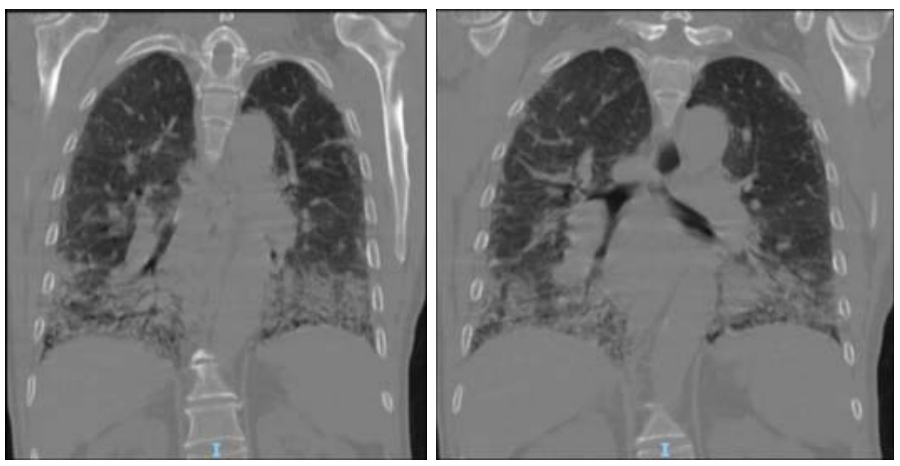

Figure 3: Initial CT Scan Coronal View.

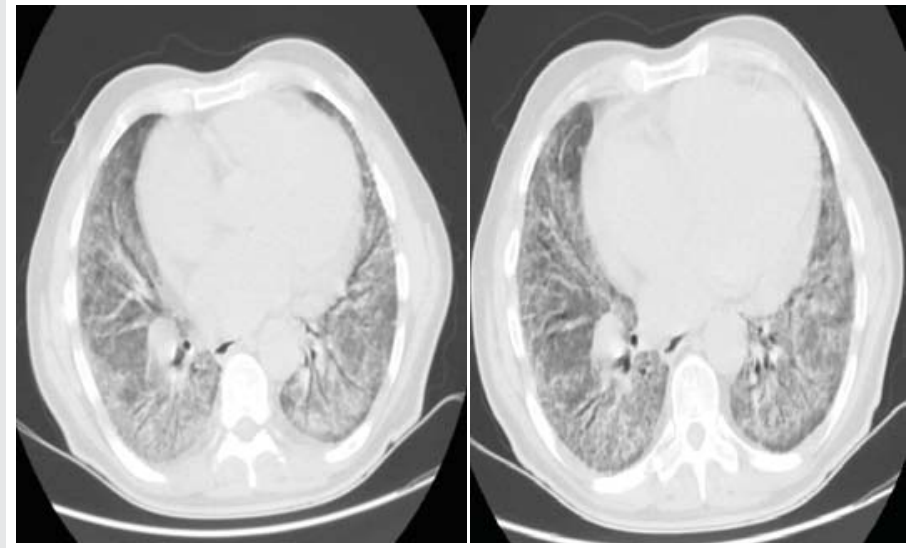

Figure 4: Follow Up Chest CT Scan Axial View.

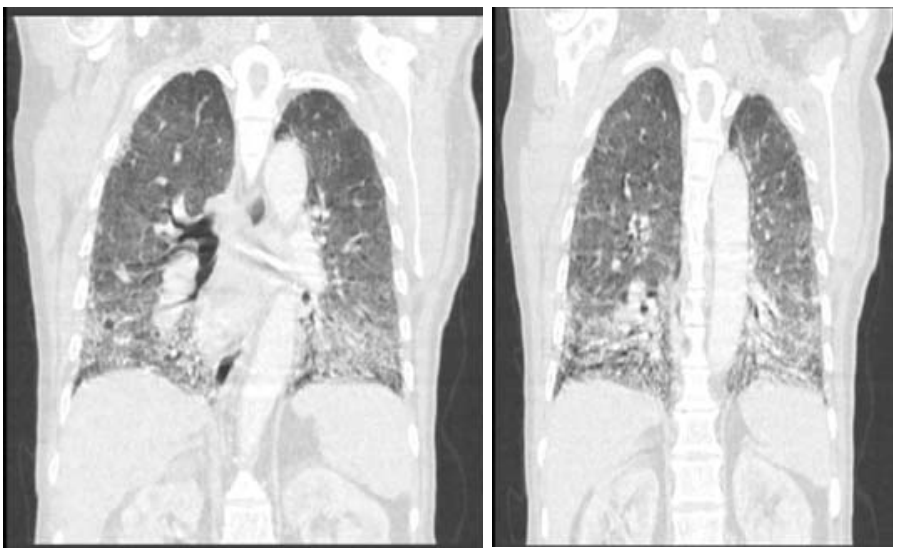

Figure 4: Follow Up Chest CT Scan Axial View.

came back positive for autoimmune sialoadenitis with four foci of lymphoid aggregate (> 50 lymphocytes) identified per 4 $\mathrm{mm}$, confirming the diagnosis.

\section{Conclusion}

Interstitial lung disease as a primary manifestation of nonsicca SS is a rare and atypical presentation. The patient met the diagnostic criteria as per the American College of Rheumatology/ European League against Rheumatism Classification Criteria for Primary Sjögren's Syndrome [5]. It has been described that SS can have interstitial pulmonary findings in up to $20 \%$ of patients [6-8]. The initial pulmonary manifestations of this syndrome have been largely underdescribed given that respiratory complaints are rarely the primary manifestation of the disease. In a recent prospective study it was shown that in non-sicca patients, ILD was the initial manifestation of SS in up to $16 \%$ [9]. As in our patient, there has been an association between anti-SSA in SS and the development of ILD [10]. In 12 to $24 \%$ of patients with primary SS, bronchiolitis is the most common airway disease $[11,12]$. The most frequently described pattern of ILD in SS patients is non-specific interstitial pneumonitis which presents with imaging findings as described in our case, other less common presentations include usual interstitial pneumonitis and lymphocytic interstitial pneumonitis. Given non-sicca symptoms, a gland biopsy was required as well as radiological examination to establish a diagnosis. This case 
heightens the importance of thorough workup of patients with ILD with unclear clinical associations. The absence of the classical sicca symptoms despite seropositivity in patients with obscure organ involvement should not deter from the exclusion of SS. Interstitial lung disease associated to primary Sjögren's syndrome requires a close follow up and aggressive therapy, as these patients are more susceptible to more progressive and severe pulmonary complications.

\section{References}

1. Gao H, Zou YD, Zhang XW, He J, Zhang J, et al. (2018) Interstitial lung disease in non-sicca onset primary Sjögren's syndrome: a large-scale case-control study. Int J Rheum Dis 21: 1423-1429. Link: https://bit.ly/3IUibq8

2. Natalini JG, Johr C, Kreider M (2019) Pulmonary Involvement in Sjogrens Syndrome. Clin Chest Med 40: 531-544. Link: https://bit.ly/3jUjC6c

3. Flament T, Bigot A, Chaigne B, Henique H, Diot E, et al. (2016) Pulmonary manifestations of Sjögren's syndrome. Eur Respir Rev 25: 110-123. Link: https://bit.ly/3jSXTvn

4. Price EJ, Rauz S, Tappuni AR, Sutcliffe N, Hackett KL, et al. (2017) on behalf of the British Society for Rheumatology Standards, Guideline and Audit Working Group, The British Society for Rheumatology guideline for the management of adults with primary Sjögren's Syndrome. Rheumatology 56: e24-e48.

5. Shiboski CH, Shiboski SC, Seror R, Criswell LA, Labetoulle M, et al. (2017) American College of Rheumatology/European League Against Rheumatism Classification Criteria for Primary Sjögren's Syndrome: A Consensus and DataDriven Methodology Involving Three International Patient Cohorts. Arthritis Rheumatol 69: 35-45. Link: https://bit.ly/3i1GRuh
6. Fauchais AL, Martel C, Gondran G, Lambert M, Launay D, et al. (2010) Immunological profile in primary Sjögren syndrome: clinical significance, prognosis and long-term evolution to other auto-immune disease. Autoimmun Rev 9: 595-599. Link: https://bit.ly/31Z0cXq

7. Ramos-Casals M, Brito-Zeron P, Seror R, Bootsma H, Bowman SJ, et al. (2015) Characterization of systemic disease in primary Sjögren's syndrome: EULARSS Task Force recommendations for articular, cutaneous, pulmonary and renal involvements. Rheumatology 54: 2230-2238. Link: https://bit.ly/2GqJS9C

8. Flores-Chavez A, Kostov B, Solans R, Fraile G, Maure B, et al. (2018) Severe, lifethreatening phenotype of primary Sjögren's syndrome: clinical characterisation and outcomes in 1580 patients (GEAS-SS Registry). Clin Exp Rheumatol 36: 121-129. Link: https://bit.ly/2GqJYOY

9. Manfredi A, Sebastiani M, Cerri S, Cassone G, Bellini P, et al. (2017) Prevalence and characterization of non-sicca onset primary Sjögren syndrome with interstitial lung involvement. Clin Rheumatol 36: 1261-1268. Link: https://bit.ly/3bBeSiL

10. Li X, Xu B, Ma Y, Li X, Cheng Q, et al. (2015) Clinical and laboratory profiles of primary Sjögren's syndrome in a Chinese population: a retrospective analysis of 315 patients. Int J Rheum Dis 18: 439-446. Link: https://bit.ly/2DAsSge

11. Papiris SA, Maniati M, Constantopoulos SH, Roussos C, Moutsopoulos HM et al. (1999) Lung involvement in primary Sjögren's syndrome is mainly related to the small airway disease. Ann Rheum Dis 58: 61-64. Link: https://bit.ly/2DAOIY8

12. Hatron PY, Wallaert B, Gosset D, Tonnel AB, Gosselin B, et al. (1987) Subclinical lung inflammation in primary Sjögren's syndrome. relationship between bronchoalveolar lavage cellular analysis findings and characteristics of the disease. Arthritis Rheum 30: 1226-1231. Link: https://bit.ly/3hWLkOZ
Discover a bigger Impact and Visibility of your article publication with Peertechz Publications

Copyright: (c) 2020 Garcia Puebla JM, et al. This is an open-access article distributed under the terms of the Creative Commons Attribution License, which permits unrestricted use, distribution, and reproduction in any medium, provided the original author and source are credited. 